\title{
U-series ages of young Tengchong volcanoes, Southeast Tibetan Plateau
}

\author{
HaIbo Zou ${ }^{1 *}$, ZiPeI GUO ${ }^{2}$, YANG PENG ${ }^{1}$, AXEL \\ SCHMITT $^{3}$, QICHENG FAN ${ }^{4}$, YONGWEI ZHAO ${ }^{4}$, AND \\ MINGJIA MA ${ }^{1}$
}

${ }^{1}$ Department of Geosciences, Auburn University, Auburn, AL 36849, USA (*correspondence: haibo.zou@gmail.com)

${ }^{2}$ State Key Laboratory of Continental Dynamics, Department of Geology, Northwest University, Xi'An 710069, China

${ }^{3}$ Institut für Geowissenschaften, Universität Heidelberg, Im Neuenheimer Feld 234-236, 69120 Heidelberg, Germany ${ }^{4}$ Institute of Geology, China Earthquake Administration, Beijing, China

The Tengchong volcanic field (TVF) in southwestern China represents rare Quaternary volcanic eruptions and associated active geothermal activities on the southeastern margin of the Tibetan Plateau. The TVF has drawn considerable attention due to its location, the unusual high-K composition of erupted magmas, and young ages. The reported eruption ages for the 3 youngest Tengchong volcanoes (Heikongshan, Dayingshan, Maanshan) are highly variable (3 ka to $790 \mathrm{ka}$ ) [e.g., 1-3] because of the challenge to accurately and precisely date young volcanic rocks by radiometric methods. Here we use high-resolution ${ }^{238} \mathrm{U}^{230} \mathrm{Th}-$ ${ }^{226} \mathrm{Ra}$ disequilibria to constrain the eruption ages and magma evolution timescales. All 3 young volcanoes exhibit wholerock $\left({ }^{226} \mathrm{Ra} /{ }^{230} \mathrm{Th}\right)$ disequilibrium ranging from 1.27 to 1.71 , indicating eruption ages of $<8 \mathrm{ka}$ (5 half-lives of ${ }^{226} \mathrm{Ra}$ ). Eruption ages of 2.9-5.1 ka for Heikongshan, 3.3-4.0 ka for Dayingshan, and 2.9-3.6 ka for Maanshan are constrained by $\left({ }^{226} \mathrm{Ra} /{ }^{230} \mathrm{Th}\right)$ evolution models. This study thus suggests Holocene eruptions for all 3 volcanoes and represents the first Holocene radiometric age for Dayingshan. We also measured ${ }^{238} \mathrm{U}^{230} \mathrm{Th}$ ages of zircons from Heikongshan, Dayingshan, and Maanshan. Zircon age populations are 54.6 $\pm 13 \mathrm{ka}$ and $94.9 \pm 4.1 \mathrm{ka}$ for Heikongshan, $59.6 \pm 5.8$ and $90.1 \pm 8.4$ for Dayingshan, and $53.8 \pm 8.7 \mathrm{ka}$ and $76.5 \pm 11 \mathrm{ka}$ for Maanshan. The new zircon age populations for Dayingshan and Maanshan are consistent with previous studies $[4,5]$. Zircon residence times for all 3 Holocene volcanoes are $\sim 50$ $\mathrm{ka}$. The similar zircon age distributions for these 3 volcanoes indicate simultaneous magmatism at $90 \mathrm{ka}$ and $55 \mathrm{ka}$. It is highly likely that the magma chambers for the 3 young volcanoes have been interconnected since $\sim 90 \mathrm{ka}$.

[1] Mu et al. (1987) Geothermics 16, 283-297. [2] Li et al., (2020) Lithos 354-355, 105173. [3] Li et al (2000) Acta Petrol. Sin. 16, 362-370. [4] Zou et al. (2010) Lithos, 118, 202-210. [5] Tucker et al. (2013) Lithos, 172-173, 214-221. 